\title{
Playful Information Literacy: Play and Information Literacy in Higher Education
}

\author{
Best Practice Article
}

Andrew Walsh*

University of Huddersfield

\begin{abstract}
It is often difficult to address higher level information literacy skills in Higher Education. This paper argues if we see information literacy as contextual rather than an absolute list of competencies, then play can give us a route to developing those higher level skills.

It takes a social constructivist approach in defining information literacy, before going on to define play and games as belonging on a wide spectrum between completely free or open play and highly structured games.

Using examples from the literature, the paper builds the argument that play is one answer towards meeting the need to develop high level information literacy in students, even though there is limited empirical research into adult play and information literacy development.
\end{abstract}

\section{Keywords:}

Information literacy; game; play

\section{*Contact:}

Andrew Walsh, University of Huddersfield, UK

e-mail: a.p.walsh@hud.ac.uk

Nordic Journal of Information Literacy in Higher Education, 2015. (C2015 Andrew Walsh

\section{(cc) BY-NC} This is an Open Access article distributed under the terms of the Creative 


\section{Introduction}

Librarians, academics, lecturers, academic skills developers and other staff in Higher Education discuss and define information literacy, but can struggle to equip students with higher level, transferable, information skills. Enabling and encouraging play, or a playful environment, may be one route to address this failure. This paper argues these points, addressing the argument that a library or university that is playful, which takes advantage of the creative explorations that play encourages, can enable students to become information literate in a way that is not currently widely addressed in Higher Education Institutions.

The two questions directly addressed are:

- Are students higher level information literacy skills explicitly addressed and developed in Higher Education?

- Can play assist in the development of higher level information literacy skills?

The paper defines information literacy and discusses issues around the development of higher level information skills within Higher Education. It moves on to discuss the nature of play, of games, and the benefits of play in adult learning.

These two areas, information literacy and play, are then pulled together to build the argument that play is an effective and relevant answer to the development of higher level information skills of students within higher education. Examples are given and some good practice illustrated where play and games are currently used to develop information literacy of students.

The paper does not address, however, the question of how higher education institutions and their staff can best use play to develop information literacy. The examples of play and games for information literacy are illustrations of small elements that exist already, not a roadmap for future implementation. Instead the paper argues why we should use, and encourage, play and a playful environment to develop these skills.

\section{Information Literacy \& higher level skills}

Information Literacy is now a well-established concept, with a rich background of research papers and practical frameworks behind it.

A typical definition of information literacy is: 'Information literacy is knowing when and why you need information, where to find it, and how to evaluate, use and communicate it in an ethical manner.' (CILIP, 2004). There have been many attempts to turn the general concept of information literacy into formal models and standards. Though some information literacy models focus on the problem solving, or research process rather than Information Literacy per se, most of the information literacy models and standards can be split into two categories. They will be referred to in this paper as the "competency based" or "relational" models and approaches.

The first, and dominant, competency based category is exemplified by the old ACRL standards (ACRL, 2000) and the many other standards based upon them; the SCONUL (2011) Seven Pillars model and the Big Blue model (JISC, 2002). These types of "competency" models list the characteristics or attributes of the "information literate person". They are primarily based on the opinions of groups of selected experts, whether as part of Delphi Studies or smaller working groups. There is significant overlap between these models and standards. The may be over interpreted by those with a positivist approach to knowledge, and used as an absolute measure of how information literate a person is. 
The second category of information literacy models originated in research initially carried out in Australia. Christine Bruce (1997) developed the first relational model, reflecting how people experience finding and using information in their own way and in the context in which they find themselves. As such it is very different to the lists of characteristics or attributes described by the competency based standards and models. These relational, or experiential based, models take the experiences of users to their core and attempt to model the richness of real information behaviour. They recognise the contextual nature of information literacy and describe variation in ideas and behaviours. This is the opposite approach to the "competency" based models which seek expert agreement on the essential characteristics that make up the information literate person.

This idea of information literacy as being contextual, depending on the person and their changing relationship to information have been taken up and developed by many researchers since, including (Andretta, 2012; Boon, Johnston, \& Webber, 2007; Bruce \& Hughes, 2010; Edwards, 2006; Lloyd, 2010; Williams, 2007).

The relational research shows that a simple list of attributes is insufficient to measure whether one is information literate. The relational models may be taken as a socially constructivist approach to the concept of information literacy as opposed to the positivist approaches implied by competency based approaches. There is no absolute truth or definition of an information literate person, but instead information literacy means subtly different things depending on the process you are undertaking or the context in which you are operating. The tension between the two positions has become a live issue in the academic library world recently due to the shift in the ACRL framework from a very list based, absolute competency presentation of information literacy, to one based more on threshold concepts that recognise that learners must understand how key concepts apply to them to become increasingly information literate and that there are no absolute measures. Indeed, they also recognise that other concepts beyond the six described may be equally important depending on context (ACRL, 2014).

Throughout this paper "high" and "low" level information literacy skills are referred to. By low level skills we mean those such as knowing what a journal article is; how to find an article using sources previously shown; how to reference that article. Higher level skills would be those such as evaluating the quality of an article; knowing what pieces of information to select to build an effective argument; synthesising new knowledge from information found; and organising the information found in a way that adds value or meaning to it.

There are gaps between the types of skills that educators would like to see developed and the lower level skills that are typically addressed explicitly or successfully developed (Anderson, Johnston, \& McDonald, 2013; DaCosta, 2010).

The practitioner side of the literature is heavily focussed on the lower level information skills and tends to use detailed models and competency standards such as the ACRL standard in Higher Education (ACRL, 2000) or the American Association of School Librarians (2009) 'Standards for the 21st Century learner in action'. These models and lists of competencies feed into tests for information literacy which claim to accurately measure the information literacy of students through multiple choice questions.

Individual practitioners or researchers interpretations of these models sometimes result in a reductionist approach, resulting in meaningless lists of competencies:

'(they) take a perfectly reasonable idea or definition and abstract it to nonsense, all in the call of making them more useful. Like pinning an insect to a board for display, in fixing information literacy in such detail, they create something lacking in life and meaning. 
They fix a dead body in place where it can no longer interact meaningfully in any way with its environment.' Walsh \& Coonan, $(2013$, p. 3).

This is despite that this reduction tends to be against the original intent of the models. The current revision process of the ACRL models reflect this, bringing in "threshold concepts" in line with, and heavily influenced by, the relational approaches to information literacy (ACRL, 2014). The threshold concepts are ideas which students must grasp to move onto the "next level" or stage of their information literacy.

The relational approaches to information literacy attempt to encourage broader approaches and a movement away from lists of competencies. As such, these have informed attempts by some academics to develop wider educational approaches to developing higher end information skills. These range from Christine Bruce's Informed Learning (Bruce, 2008) which brings a focus on using information to the centre of learning; through the recognition of the mass of low quality information available overwhelming many of us (Whitworth, 2009) and that we may need to carefully scaffold students interactions with it as they learn to be information literate (Brabazon, 2013).

Attempts have been made to recognise the contextual nature of information literacy, to raise awareness of the need to develop these skills, and to consider educational approaches that address not just lower end information skills, but the more valuable and transferable higher level skills too. However, these are the exceptions rather than the rule. In general, the key skills addressed tend to be low level (Markless, 2004; Wang, 2007). This is not through a lack of desire or willingness, indeed the gap between desired skills and those which are explicitly addressed is discussed as a concern (e.g. Jacqui Weetman DaCosta, 2010; Saunders, 2012) and there is a desire amongst the expert community to explicitly address higher level skills and take a more holistic view of information literacy and learning (Secker, 2011).

If we look at attempts to measure information literacy, we see an overwhelming use of simplistic tools such as multiple choice questionnaires which often fail to show their validity (Walsh, 2009) in measuring the complex and contextual dependent nature of information literacy. Instead they understandably reinforce the emphasis on lower level information skills, because those are the skills that are easiest and quickest to measure.

It would benefit students across the academy to develop their information literacy to encompass higher level skills, which can be helped by using the relational models, including the threshold concepts outlined in the new ACRL framework (ACRL, 2014). If equipped to explore and understand "interesting" ideas and information sources, to feel confident in questioning and arguing using a full array of information skills, they will be better equipped to study at a higher level. Teaching and assessing explicitly only lower level information skills equips students poorly for their early days at university, never mind their full academic and vocational journeys. Enabling students to develop true, high level, transferable information literacies, equips them more effectively to perform at the highest level at our universities and beyond that in the workplace.

Perhaps alongside this, we should recognise within our definitions of information literacy those tensions between low and high level skills, and the contrast between relational ideas of information literacy and the competency based approaches. As such, a starting point for a new working definition of Information literacy may be the one suggested by Secker and Coonan (2013) below, which moves away from the listing of particular skills (search, evaluate, reference) found in the mainstream definitions, to one closer to the ideas of Informed Learning (Bruce, 2008) and the overarching concepts of relational information literacy (Secker \& Coonan, 2013). 
Information literacy is a continuum of skills, behaviours, approaches and values that is so deeply entwined with the use of information as to be a fundamental part of learning, scholarship and research. It is the defining characteristic of the discerning scholar, the informed and judicious citizen and the autonomous learner. (p. XXII)

\section{What is play?}

So how can students be supported to switch from a conceptual model where there are right versus wrong answers? To switch them from a "black and white" point of view, to one composed of a kaleidoscope of colour, where there is no longer "correct" sources of information, simply interesting or illuminating ones? One answer, discussed below, is the use of play. Play as a concept can be difficult to define precisely, though we may instinctively recognise it. The same applies to the idea of "games". In the following section we will define play and games for the purposes of the argument in this article.

A classic and widely accepted definition of play can be found in Huizinga (1955): Summing up the formal characteristic of play, we might call it a free activity standing quite consciously outside 'ordinary' life as being 'not serious' but at the same time absorbing the player intensely and utterly. It is an activity connected with no material interest, and no profit can be gained by it. It proceeds within its own proper boundaries of time and space according to fixed rules and in an orderly manner. It promotes the formation of social groupings that tend to surround themselves with secrecy and to stress the difference from the common world by disguise or other means.(p. 13)

So play steps "outside" of normal or ordinary life. It proceeds in its own boundaries, where rules apply, though they may be quite different to the rules that govern normal life. The boundaries that are set (of time and space) allow these rules to operate, as they are strictly constrained and the players know where the "play" world begins and the "normal" world ends. Players seek to define these boundaries even more strongly using whatever means are available, such as "disguise" in Huizinga's definition.

A neater, easier to explain definition is available from Brown, who defines play by splitting it into some key features (Brown \& Vaughan, 2010, p. 17), stating that play is: "Apparently Purposeless (done for its own sake); Voluntary; has Inherent Attraction; Freedom from time; Diminished consciousness of self; Improvisational potential; and Continuation desire."

So play is something that may not have an obvious purpose or destination. We can't force people to play, as it is voluntary, we can simply provide the opportunity to play and ensure its inherent attraction is obvious to learners. Learners are likely to "lose themselves" in play, losing track of time or awareness of their own normal "self", allowing them to improvise in ways they may otherwise struggle to do. When learners are truly playing, it motivates them to continue, not relying on extrinsic, external motivations such as formal assessments or grades.

It is important that no-where in the definitions of play does it say that play is fun. In fact, activities we normally think of as serious work may well be classed as play, within Sutton-Smith making it clear that 'the opposite of play is not work, it is depression' (Sutton-Smith, 2001). In the case of information literacy in higher education, the research process itself can be seen as playful, with students and academics spending many hours "lost" in their research. A useful concept from the literature on play and games to introduce here is one of flow (Csikszentmihalyi, 1992), where there is a balance sought between the challenge of playing the game (or gaining new skills and knowledge) and finishing the game (or learning activity). If the challenge is too hard, then people will fail to complete, giving up in frustration. If the challenge is too easy, the game (or learning activity) can be seen as boring, not worth spending time 
completing. Flow is concerned with balancing difficulty with player skill, especially as they improve their skill as they progress through a game. Game designers spend a great deal of time considering flow, librarians, database developers, and lecturers rarely do when designing interfaces or learning activities.

If play is a little difficult to define, then games are even more difficult. Some definitions of games are offered here, but we must treat these as guidance and apply common sense and experience to any application of them. To some extent this is because play covers a wide spectrum of activity which includes games, though they are often treated as a separate idea to play in the educational literature for convenience. Caillois, in his sociological work on play, brings play and games together on a spectrum of play forms and of types of play. Ludic (very structured) play, which many formal games would fall under, is simply one end of a spectrum with paidia which is largely unstructured and open (Caillois \& Barash, 2001). What is most commonly described as "games" sit on this spectrum of play, containing varied amounts of ludus and paidia. So the definitions of a game are necessarily difficult to pin down exactly as activities that we naturally recognise at games could sit in very different places within this overall spectrum described by Caillois.

Indeed, Wittengstein claimed that games were undefinable, prompting Bernard Suits (1978) to develop and tested a new definition. This is now a classic definition of a game:

To play a game is to engage in activity directed towards bringing towards a specific state of affairs, using only means permitted by rules, where the rules prohibit more efficient in favour of less efficient means, and where such rules are accepted just because they make possible such activity. (p. 34)

Or we could take a more recent, concise definition such as Salen \& Zimmerman (2004, p. 96): "A game is a system in which players engage in an artificial conflict, defined by rules, that results in a quantifiable outcome."

There are many overlapping features of the many generally accepted definitions. An attempt to draw out this common ground and redefine games in the light of increased computer gaming is available from Juul (2003).

A game is a rule-based formal system with a variable and quantifiable outcome, where different outcomes are assigned different values, the player exerts effort in order to influence the outcome, the player feels attached to the outcome, and the consequences of the activity are optional and negotiable. (p. 5)

As it can be seen from the definitions above a key feature of games is that they impose rules on what may otherwise be thought of as pure (paidic) play. So at the simplest possible definition, games can be thought of as play with more formal rules.

Games are therefore included in this article and treated as instances of play, particularly in the following section. They are play, but often use to describe the more structured form of play. The literature is much richer on the use of games in education than play without these imposed rules, the more paidic end of Caillois' scale. However, it must be seen that play has a much wider meaning than often discussed in this game based learning literature and that the encouragement of playfulness without the strictures of some formal games can be as valid, if not more so, than introducing strictly controlled games into learning. The firmer rules of the more structured nature of play within formal "games" make it easier to introduce play into learning and libraries, but it is nonetheless still a form of play. 


\section{Benefits of play in adult learning and information literacy development}

The intersection of play, game based learning and higher education can be problematic. This section will discuss some of the evidence towards the benefits of using games and play in education.

The key problem with considering evidence in this field is the pedagogical background to much of the game based interventions. In short, there often isn't an obvious or firm pedagogical foundation for many game based learning projects. W.H.Wu, Hsiao, P.L.Wu, Lin, \& Huang (2012) carried out a meta-analysis of game based learning projects and concluded that the vast majority (567 out of 658 studies) failed to use a clear learning theory. Those that did, largely declared a contructivist approach (48 out of 91). This lack of explicit pedagogical awareness reflects a tendency in game based learning projects to focus on "engagement" over learning (e.g. Galway, Gard, \& Collinson, 2014). They attempt to increase engagement with learning activities through games, rather than construct sound learning activities that may be game like in nature. This is despite concerns amongst some game based learning researchers about the degree to which games intrinsically increase learner engagement without careful and appropriate design and implementation (Whitton, 2011a, 2011b) although well-known names such as Prensky (2002) stress engagement and "fun" as being key drivers for game based learning.

Despite these issues, there is published research that shows the learning benefits of games and play in the education of adults. This tends to be split into two separate fields, though there are significant overlaps. Game based learning (which itself has tensions within, such as that between "serious games" and game based learning in general) which discusses the benefits of games or simulations and "play" (without explicitly mentioning games) which tends to be linked with creativity, often in artistic or craft domains.

Hromek and Roffey (2009, p. 631), place game based learning as part of "experience based learning", which they refer to as "a pervasive and subtle process, resembling life in many ways". They list some of the attributes they allocate to experience based learning, which they contrast to the more didactic approaches such as straightforward lecturing.

This is echoed in much of the game based research. Whitton (2012), summarising the benefits of game based learning as Playfulness; Practice; Engagement; Scaffolding; Feedback; and Digital Literacy (when referring to computer games).

Playfulness can allow the learner to 'experiment, explore and try out new things without risk of negative outcomes [...] The playful state that games can engender can spark creativity, innovation and new ideas'. Practice allows 'reflection on progress [...] opportunity to keep attempting the same task and refining the playing strategy until the goal has been achieved'. Engagement, often seen as a key feature of games based learning, is based on a toolbox of 'elements that support ongoing engagement while the learner is playing'. Scaffolding allows problems or activities to 'start small and gradually increase in difficulty'. Feedback 'on actions is essential to be able to reflect in their effectiveness and modify them' and the immediate feedback that games offer is 'one of the reasons why games can be so powerful for learning. Finally, improvement of digital literacy skills can be often embedded in game design, allowing 'players to experience visual and aural media simultaneously, and to manage data gathering and extraction from multiple competing sources, ideas closely related to media and information literacy. (Whitton, 2012, p. 15-17).

Playfulness, practice, and engagement all refer to open play (paidia) as much as formal games, with the more formal structures of games (ludus) enabling additional scaffolding and feedback. 
It can be seen from this that play, including games, can help build strong elements of practical and in depth learning into education. They address not the learning of facts or rote repetition of basic skills, but of experiential learning, of problem solving, creativity and innovation. They do this by engaging (if well designed) students in tasks that are well scaffolded and offering immediate and clear feedback within a playful environment that encourage reflection, practice and engagement. Well designed and created games have the potential to be models of best practice in higher education, including information literacy development.

Play has been seen as a key part of learning in children, but not as explicitly in adults. However, Corbeil argues a continuity from play in children's learning and adult's learning that researchers often shy away from, rejecting play as an activity limited to children and arguing that it is an integral part of human development, whatever our age (Corbeil, 1999).

Writings on play from a sociological and development background recognise the key place play has within education. A key writer on play, Sutton-Smith has 'play as progress' as one of his seven key rhetorics of play (Sutton-Smith, 2001). This form, or rhetoric, of play has at its centre the idea that play enables personal and educational development. Authors such as Pat Kane and Stuart Brown bring the importance of play out of the ideas of child development into a vital part of adult learning and development (Brown \& Vaughan, 2010; Kane, 2005).

Much of the literature that focusses on open play, that is, play less controlled by formal rules, rather than play within firmly structured games, in adult learning takes a different angle to the more general game-based learning literature. These researchers often recognise that play allows safe experiential learning, but the literature tends to focus more on creativity. Providing playful learning opportunities is seen as a way to use metaphors and safe places to learn and explore (Francis, 2009; Gauntlett, 2011). They discuss ideas and teaching strategies that allow students to be creative, to think with their hands. In many of the examples they give, however, it is clear that they what these activities allow is play. They provide materials that either directly or indirectly represent information that a student needs to manipulate, to assess and to rerepresent. The learning spaces offered for these interactions helps create the 'magic circle' of play. Students are allowed the freedom within fairly loose sets of restrictions to interact with the materials and the information they represent. The safety of the play environment helps the students move through the learning process to deeper understanding.

Cooper explicitly argues that play is particularly important at transitional periods, in new situations and in learning new ideas, particularly as it increasing the social aspects of learning. It provides "a non-threatening forum for experimentation and a means to form a cohesive subculture/group in which the student feels a sense of belonging or relatedness". (Cooper, 1996, p. 33)

These two areas of literature most obviously overlap in the creation of alternate reality games (ARGs), games that let the player enter into an alternate game world that runs alongside real life. These can be complex to build and difficult to entice learners into, but deliberately inculcate a sense of free play and exploration into the game. There is evidence to suggest that these are a suitable vehicle to improve students' media and information literacies in higher education (Chess \& Booth, 2014; Ireton, Pitts, \& Ward, 2014; Piatt, 2009) particular in induction settings as students learn to navigate a new information environment.

\section{Play and information literacy}

There is a difference between going through the motions of a research process to find a required answer, compared to exploring the research landscape, where researchers may spend many hours experimenting, reading and wandering through the literature to find new connections. Thus lower level information skills may be considered more as work than play. Perhaps play can 
be one answer to the need to address information literacy education in general, encouraging exploration of the information landscape and the re-organisation of it in interesting ways. The exploration of ideas and the construction of context specific knowledge that play and games enable so well, tend to fit better into the relational models than the older competency based models. Play allows people to construct and explore their own concepts and those of their peers, encouraging a social constructivist approach to developing information literacy. It moves away from the idea that there are individual, absolute measures of an information literate person and allows freedom to construct individual and social "truths" about what is information literate behaviour in that context.

There have been many attempts to use games to support the development of information literacy within, though less which explicitly try to use play without the formal constraints of gameplay. This is understandable, as well structured games can be easier to introduce that more open play in teaching interventions.

Non-digital games 'the original learning technology' as Crawford (Crawford, 1984, p. 15) states, have a long history in education, but there is limited recent literature related to them particularly in libraries. Games such as SEEK! (http://eprints.hud.ac.uk/15377/) and informal, often ad-hoc games created by individual educators, are perhaps seen as too 'ordinary' or 'everyday' to appear in the literature, though they may appear in more practical texts (McDevitt, 2011). Instead, the literature on games and information literacy is dominated by the creation and implementation of digital games, though occasionally these cite earlier table top prototypes as part of their development (Gallegos, Allgood, \& Grondin, 2007).

A large and significant category of library games are those associated with induction, or orientation to the library, rather than addressing those skills primarily thought of as information literacy skills. They are often "treasure hunt" style activities and are the largest category of game like activities that sit on the more "openly playful" end of the open / structured play spectrum. Games such as these (Piatt, 2009; Thompson, Kardos, \& Knapp, 2008), use playful elements that give participants "permission" to play in the library and university spaces. They demarcate a safe, magic circle (Salen \& Zimmerman, 2004, p. 94-96), in which 'normal life' does not apply. When learners engage in these activities, they step outside of the potentially intimidating and serious library space, and into the 'safe' play space. This enables them to feel safe to explore, to experience the library in a way the otherwise may not. They can go beyond the tasks directly set in the activity as long as they are within its bounds and form their own ideas and construct their own knowledge in a safe environment. The activity itself changes the user perceptions of the environment and is placed at the more playful, less structured end of the game spectrum. Search skills are often a focus of library games, but tend to concentrate on lower level aspects of search and information literacies. Topics such as Boolean operators, use of the library catalogue, or accessing particular library databases abound. The need to formalise rigid rules when creating digital games may be largely responsible for this. Unlike non-digital games which may include human direction and elements of negotiation, digital games must have fairly rigid structures set in place from the start. As a result, even quite ambitious games that allow elements of exploration (Markey et al., 2008a; Markey et al., 2008b; Taylor, Davis, Gonzalez, Dinsmore, \& Frey, 2008) struggle to move onto higher level search skills. To be manageable to create they must often reflect what they developers see as information literate behaviour and present that as "true" or absolute before players can move through the game.

Some games do explicitly try to address higher level skills, for example encouraging exploration of wider material. Perhaps for the reason above, they are often quite limited. The restrictions of developing a fully blown (normally digital) game can mean that higher-level skills are addressed in a fairly limited way. 
A perennial topic covered in information literacy instruction is that of plagiarism, citation and referencing. As may be imagined, very good games that address these skills (e.g. http://library.northampton.ac.uk/liberation/ref/cat.php) can still be quite mechanical in nature. Even with high production values, games on these topics tend to address the 'how' of these skills rather than the 'why' and provide limited opportunities to learn skills transferable to new contexts.

There are elements of good practice in using games for information literacy development (Markey et al., 2009). However, as previously discussed in the wider literature, many of these tend towards 'engaging' users rather than concentrating on firm pedagogic foundations. The games that show the most promise in developing higher level skills tend to be those with looser, more playful elements, which often suit non-digital games. It is rare for the literature to explicitly address the more playful, unstructured end of the game based learning spectrum, and when they do argue for more play in library education, they typically address children's education rather than adult's (e.g. Powell, 2013).

A sensible approach to fully developing information literacy in Higher Education, if we believe in a socially constructed, relational idea of information literacy, may be a renewed emphasis on non-digital formats in games. There are echoes of this within the activities outlined below that are closer to being open play than highly structured (ludic) play.

These play exercises may be somewhat abstract in nature, allowing students to play with ideas or concepts, or may be quite explicitly addressing information literacy. For instance, exercises may encourage making links between text and keywords (Francis, 2009), or in a case witnessed by the author, students physically cut up and re-arrange a journal article to play with the ideas and extract or re-organise the concepts within. Creative lecturers such as GröppelWegener may prompt students to think about sources of information in different ways, visualising and drawing them, and so to play with the ideas embedded within them (GroppelWegener \& Walton, 2013).

Playing with physical objects, such as some of those above, or other commonly used techniques such as creating models using modelling clay or Lego (Kristiansen \& Rasmussen, 2014), also draw in ideas of embodied cognition (Wilson, 2002), where the play environment free the learners to 'think with their hands' and so offload some of the cognitive load. It is interesting, but not surprising, that there is less discussion of open, less structured play and adult learning or information literacy development available, with formal, structured games dominating the literature. If anything, forcing play into more structured games could reduce the opportunities to explore and achieve full understanding of the meaning of the object and phenomenon being studied.

In the case of learning high-level, generic and transferable skills, both formal, highly structured, games and less structured play have potential, though providing opportunities to play with ideas, concepts, materials, seems to have the most value. It is important to note again, however, that games can refer to a large spectrum of activity that includes free play.

\section{Conclusion}

It can be seen that higher level information literacy skills are rarely explicitly addressed in Higher Education, though it would be valuable to do so (DaCosta, 2010; Markless, 2004; Saunders, 2012; Secker, 2011; Wang, 2007). There have been attempts to create pedagogical approaches using the ideas embedded in relational information literacy that would help a more explicit addressing of this issue (Brabazon, 2013; Bruce, 2008; Secker \& Coonan, 2013; Whitworth, 2009). This may be due to a tension between the time and effort required to treat 
information literacy as an absolute set of skills, compared to the trickier to handle idea that it is socially constructed and unique to every learner and context.

Play brings a freedom to explore and innovate, creating 'safe' ways of developing skills such as those required to navigate in the complex, demanding, modern information landscape (Brown \& Vaughan, 2010; Corbeil, 1999; Hromek \& Roffey, 2009; Kane, 2005; Sutton-Smith, 2001; Whitton \& Moseley, 2012). It can therefore effectively support the development of those higher level, transferable, information literacy skills, though there have been only limited steps towards this so far. Those attempts to use play have been primarily using the more ludic, or structured end of the scale through games, sometimes with the emphasis on engagement rather than quality of learning. The more paidia (Caillois \& Barash, 2001) end of the play scale, as opposed to more ludic games, used have largely been within the 'creative' subject areas, such as art and design (Francis, 2009; Gauntlett, 2011) and within the more complex game design of alternate reality games (Chess \& Booth, 2014; Ireton, Pitts \& Ward, 2014; Piatt, 2009). They do, however, show some ideas which can be used more widely to develop higher level information literacy within students.

There are many ways in which Higher Education institutions can encourage a playful attitude. This paper suggests that play could be a missing element in the way libraries and universities tend to operate. Creating playful libraries can be a major step towards developing higher level information skills and recognising that information literacy is a socially constructed idea.

A playful library and a playful university could help to produce playful, creative graduates who can apply the same creative approach to their future careers as we enable in their learning. A student who feels safe to play will overcome challenges and think of new, innovative, solutions, compared to one who follows set paths who may always be reluctant to depart from that path and discover new knowledge, meet new challenges, develop new solutions. The challenge this paper leaves open for future research and discussion is to consider how a playful approach to study and information literacy can be inculcated in higher education institutions. 


\section{References}

ACRL. (2000). Information Literacy Competency Standards for Higher Education. Chicago: ACRL.

ACRL. (2014). Framework for Information Literacy for Higher Education. Retrieved from http://www.ala.org/acrl/standards/ilframework

American Association of School Librarians. (2009). Standards for the 21st-Century Learner in Action. Retrieved from http://www.ala.org/aasl/standards-guidelines/learningstandards

Anderson, T., Johnston, B., \& McDonald, A. (2013). Information literacy in adult returners to Higher Education: student experiences in a university pre-entry course in a UK university. Library and Information Research, 37(114), 55-73.

Andretta, S. (2012). Ways of experiencing information literacy: making the case for a relational approach. Oxford: Chandos.

Boon, S., Johnston, B., \& Webber, S. (2007). A phenomenographic study of English faculty's conceptions of information literacy. Journal of Documentation, 63(2), 204-228. doi: 10.1108/00220410710737187

Brabazon, T. (2013). Digital Dieting: From Information Obesity to Intellectual Fitness: Ashgate Publishing Ltd.

Brown, S. L., \& Vaughan, C. C. (2010). Play: how it shapes the brain, opens the imagination, and invigorates the soul. New York: Avery.

Bruce, C. (1997). The seven faces of information literacy. Adelaide, S. Aust: Auslib.

Bruce, C., \& Hughes, H. (2010). Informed learning: A pedagogical construct attending simultaneously to information use and learning. Library and Information Science Research, 32(4), A2-A8. doi: 10.1016/j.lisr.2010.07.013

Bruce, C. (2008). Informed Learning. Chicago: American Library Ass.

Caillois, R., \& Barash, M. (2001). Man, play, and games. Urbana: University of Illinois Press.

Chess, S., \& Booth, P. (2014). Lessons down a rabbit hole: Alternate reality gaming in the classroom. New Media \& Society, 16(6), 1002-1017.

CILIP. (2004). Definition of Information Literacy. Retrieved from http://www.cilip.org.uk/cilip/advocacy-campaigns-awards/advocacycampaigns/information-literacy/information-literacy

Cooper, M. K. (1996). Play as a component of the adult educational experience. Paper presented at the Proceedings of the Fifteenth Annual Midwest Research-to-Practice Conference in Adult, Continuing, and Community Education.

Corbeil, P. (1999). Learning from the Children: Practical and Theoretical Reflections on Playing and Learning. Simulation \& Gaming, 30(2), 163-180. doi:10.1177/104687819903000206

Crawford, C. (1984). The art of computer game design. Berkley, California: Mcgraw-Hill. 
Csikszentmihalyi, M. (1992). Flow: the psychology of happiness. London: Rider.

DaCosta, J. W. (2010). Is There an Information Literacy Skills Gap to Be Bridged? An Examination of Faculty Perceptions and Activities Relating to Information Literacy in the United States and England. College \& Research Libraries, 71(3), 203-222. doi: 10.5860/0710203

Edwards, S. L. (2006). Panning for gold: information literacy and the Net Lenses Model. Adelaide, S. Aust: Auslib.

Francis, P. (2009). Inspiring writing in art and design: taking a line for a write. Bristol, UK: Intellect.

Gallegos, B., Allgood, T., \& Grondin, K. (2007). Quarantined: The Fletcher Library Game Project. Paper presented at the LOEX.

Galway, P., Gard, L., \& Collinson, T. (2014). Engaging students with creative library staff: the game's afoot! ALISS Quarterly, 9(2), 16-20.

Gauntlett, D. (2011). Making is connecting: the social meaning of creativity, from DIY and knitting to YouTube and Web 2.0. Cambridge: Polity.

Groppel-Wegener, A., \& Walton, G. (2013). The Fishscale of Academicness. In A. Walsh \& E. Coonan (Eds.), Only Connect ... Discovery Pathways, library explorations and the information adventure (pp. 15-38). Huddersfield: Innovative Libraries.

Hromek, R., \& Roffey, S. (2009). Promoting Social and Emotional Learning With Games: It's Fun and We Learn Things. Simulation \& Gaming, 40(5), 626-644. doi:10.1177/1046878109333793

Huizinga, J. (1955). HOMO LUDENS: A Study of the Play-Element in Culture. Boston: Beacon Press.

Ireton, D., Pitts, J., \& Ward, B. (2014). Library Discovery through Augmented Reality: A game plan for academics. International Journal of Technology, Knowledge and Society, 9(4), 119-128.

JISC. (2002). The Big Blue final report: The Joint Information Systems Committee.

Juul, J. (2003). The Game, the Player, the World: Looking for a Heart of Gameness. Paper presented at the Level Up: Digital Games Research Conference Proceedings, Utrecht.

Kane, P. (2005). The play ethic: a manifesto for a different way of living. London: Pan.

Kristiansen, P., \& Rasmussen, R. (2014). Building a Better Business Using the Lego Serious Play Method. New Jersey: John Wiley \& Sons Inc.

Markey, K., Swanson, F., Jenkins, A., Jennings, B. J., Jean, B., Rosenberg, V., . . Frost, R. L. (2008a). Designing and testing a web-based board game for teaching information literacy skills and concepts. Library Hi Tech, 26(4), 663-681. doi:10.1108/07378830810920978

Markey, K., Swanson, F., Jenkins, A., Jennings, B. J., St. Jean, B., Rosenberg, V., . . Frost, R. L. (2008b). The Effectiveness of a Web-based Board Game for Teaching Undergraduate Students Information Literacy Concepts and Skills. D-Lib Magazine, 14(9/10). doi:10.1045/september2008-markey 
Markey, K., Swanson, F., Jenkins, A., Jennings, B., St. Jean, B., Rosenberg, V., . . F Frost, R. (2009). Will Undergraduate Students Play Games to Learn How to Conduct Library Research? The Journal of Academic Librarianship, 35(4), 303-313. doi:10.1016/j.acalib.2009.04.001

Markless, S. (2004). Teaching your Users: What you Really Need to Know. Legal Information Management, 4(4), 221-225. doi: 10.1017/S1472669604001926

McDevitt, T. (Ed.). (2011). Let the games begin! Engaging students with field-tested interactive information literacy instruction. New York: Neal-Schuman.

Piatt, K. (2009). Using alternate reality games to support first year induction with ELGG. CampusWide Information Systems, 26(4), 313-322. doi: 10.1108/10650740910984646

Powell, A. (2013). Get in the game: Encouraging play and game creation to develop new literacies in the library. Library Trends, 61(4), 836-848.

Prensky, M. (2002). The motivation of gameplay: The real twenty-first century learning revolution. On the Horizon, 10(1), 5-11.

Salen, K. \& Zimmerman, E. (2004). Rules of play: game design fundamentals. Cambridge, Mass: MIT.

Saunders, L. (2012). Faculty perspectives on information literacy as a student learning outcome. The Journal of Academic Librarianship, 38(4), 226-236.

Secker, J. (2011). A new curriculum for information literacy: expert consultation report. Retrieved from http://eprints.lse.ac.uk/37680/

Secker, J., \& Coonan, E. (2013). Rethinking information literacy: a practical framework for supporting learning. London: Facet Publishing.

SCONUL. (2011). The Seven Pillars of Information Literacy, Core Model for Higher Education. London: SCONUL.

Suits, B. H. (1978). The grasshopper : games, life, and Utopia. Toronto : University of Toronto Press

Sutton-Smith, B. (2001). The ambiguity of play. Cambridge, Mass: Harvard University Press.

Taylor, L. N., Davis, V., Gonzalez, S. R., Dinsmore, C., \& Frey, C. (2008). Bioactive : a game for library instruction at the University of Florida. In A. Harris \& s. Rice (Eds.), Gaming in Academic Libraries: Collections, Marketing, and Information Literacy.. Chicago: Association of College \& Research Libraries.

Thompson, K., Kardos, R., \& Knapp, L. (2008). From tourist to treasure hunter: a self-guided orientation programme for first-year students. Health Information \& Libraries Journal, 25(1), 69-73. doi: 10.1111/j.1471-1842.2007.00760.x

Walsh, A. (2009). Information Literacy Assessment: Where do we start? Retrieved from http://eprints.hud.ac.uk/2882/1/Information

Walsh, A., \& Coonan, E. (Eds.). (2013). Only Connect ...Discovery pathways, library explorations, and the information adventure. Huddersfield: Innovative Libraries. 
Wang, L. (2007). Sociocultural Learning Theories and Information Literacy Teaching Activities in Higher Education. Reference \& User Services Quarterly, 47(2), 149.

Whitton, N. (2011a). Encouraging Engagement in Game-Based Learning. International Journal of Game-Based Learning (IJGBL), 1(1), 75-84. doi: 10.4018/ijgbl.2011010106

Whitton, N. (2011b). Game Engagement Theory and Adult Learning. Simulation \& Gaming, 42(5), 596-609. doi: 10.1177/1046878110378587

Whitton, N. (2012). Good game design is good learning design. In N. Whitton \& A. Moseley (Eds.), Using games to enhance learning and teaching: A beginner's guide (pp. 9-20). Abingdon: Routledge.

Whitton, N., \& Moseley, A. (2012). Using Games to Enhance Learning and Teaching : A Beginner's Guide: A Beginner's Guide. Hoboken: Taylor and Francis.

Whitworth, A. (2009). Information obesity. Oxford: Chandos.

Williams, D. (2007). Secondary school teachers' conceptions of student information literacy. Journal of Librarianship and Information Science, 39(4), 199-212. doi:10.1177/0961000607083211

Wilson, M. (2002). Six views of embodied cognition. Psychonomic bulletin \& review, 9(4), 625636. doi: 10.3758/BF03196322

Wu, W. H., Hsiao, H. C., Wu, P. L., Lin, C. H., \& Huang, S. H. (2012). Investigating the learningtheory foundations of game-based learning: a meta-analysis. Journal of Computer Assisted Learning, 28(3), 265-279. doi: 10.1111/j.1365-2729.2011.00437.x 